\title{
Scorul APGAR - cel mai fidel indicator pentru riscul de infectie neonatală, corelat cu numărul de zile de internare și cu paritatea
}

\author{
Titiana Cornelia Cotoi', Raluca Niculescu², Adrian-Horațiu Sabău², \\ Mihaela Cornelia Șincu², Diana Chiorean², Laura Mihaela Suciư ${ }^{3}$, Daniela Lucia Muntean ${ }^{4}$ \\ ${ }^{1}$ IOSUD, Universitatea de Medicină, Farmacie, Știinţe și Tehnologie \\ "George Emil Palade", Tg. Mureș, România \\ ${ }^{2}$ Departamentul Patologie, Spitalul Clinic Judeţean Mureș, Tg. Mureș, România \\ ${ }^{3}$ Clinica Neonatologie, Universitatea de Medicină, Farmacie, Știinţe și Tehnologie \\ „George Emil Palade“ din Târgu Mureș, România \\ ${ }^{4}$ Facultatea de Farmacie, Universitatea de Medicină, Farmacie, Știinţe și Tehnologie \\ „George Emil Palade“, Tg. Mureș, România
}

\begin{abstract}
REZUMAT
Introducere. Infecțiile la nou-născuți reprezintă un subiect studiat la scară largă la nivel mondial. Infecțiile neonatale sunt de două tipuri: cele cu debut precoce, dobândite, cu microrganisme provenite de la nivelul tractul genital feminin sau peripartum, și cele cu debut târziu, apărute ca urmare a unor proceduri invazive, din cauza unor germeni nosocomiali sau invazive, peri- sau postpartum.

Obiective. Scopul studiului a fost identificarea unor factori predictivi ai infectiilor neonatale cu debut precoce. Material și metode. Am realizat un studiu prospectiv în cadrul Clinicii de Neonatologie din cadrul Spitalului Clinic Județean din Tg. Mureș, România, în perioada ianuarie 2017 - martie 2019.

Rezultate. În cadrul studiului, au fost incluși 120 de nou-născuți, dintre care $15(12,5 \%)$ au avut scorul APGAR 10 la 1 minut. La 5 minute, $57(47,5 \%)$ au avut APGAR 10. Tipul nașterii: $59(49,2 \%)$ dintre pacienți au fost născuți pe cale vaginală și $61(50,8 \%)$ prin cezariană. Vârsta gestațională medie a fost de 39,04 săptămâni. Greutatea medie la naștere a fost $3.197,33 \mathrm{~g}$, iar la externare a fost de $3.126,12 \mathrm{~g}$. Media lungimii fătului a fost $51,62 \mathrm{~cm}$, iar media perimetrului cranian a fost $33,48 \mathrm{~cm}$. Cel mai frecvent, pacienții au prezentat patologie infecțioasă neonatală precoce $(n=40)$, frecvent asociată cu afectarea sistemului pulmonar. Durata medie de spitalizare a fost de de 4 zile, cu o medie de spitalizare de 6,15 zile. Scorul APGAR la 1 minut și la 5 minute s-a corelat semnificativ statistic cu numărul de zile de internare și cu paritatea.

Concluzii. Scorul APGAR la 1 minut și la 5 minute a reprezentat în studiul nostru cel mai fidel indicator pentru riscul de infecție neonatală. Valorile sale s-au corelat cu numărul de zile de internare. Numărul de zile de internare s-a corelat și cu paritatea.
\end{abstract}

Cuvinte cheie: infecții neonatale precoce, scor APGAR, proteina C reactivă

\section{INTRODUCERE}

Infecţiile la nou-născuţi reprezintă un subiect studiat pe scară largă la nivel mondial. Vulnerabilitatea crescută a nou-născuţiilor la infecţii, comparativ cu alte vârste, a fost demonstrată atât la nivel celular, cât şi la nivel molecular $(1,2)$. Imaturitatea şi lipsa de experienţă a sistemului imun înnăscut şi adaptativ fac ca nou-născuţii, în special cei născuţi prematur, să fie mult mai susceptibili la infecţii, atât bacteriene, cât şi virale (3).

Mecanismele fiziopatologice implicate în dezvoltarea infecţiilor neonatale nu sunt complet înţelese. Se pare că imaturitatea imunitară şi virulenţa agenţiilor microbieni explică parţial diferenţele apărute între nou-născuţi infectaţi cu aceiaşi agenţi patogeni, frec- 
vent dobândiţi în perioada neonatală. Descoperirea rolului anticorpilor materni (Abs) - ca, de exemplu, polizaharide anticapsulare grupa B streptococică (GBS) - în protejarea nou-născuţilor împotriva sepsisului neonatal a fost un punct de reper în descoperirea bazelor moleculare ale susceptibilităţii la infecţie a nou-născutului (1).

Infecţiile neonatale se împart în infecţii cu debut precoce, dobândite, cu microorganisme provenite de la nivelul tractului genital feminin, apărute de cele mai multe ori prin infecţie amniotică ascendentă sau peripartum, şi cele cu debut târziu, apărute ca urmare a unor proceduri invazive din cauza unor germeni nosocomiali sau prin invazie peri sau postpartum. Susceptibilitatea la infecţie este agravată de imaturitatea imunologică relativă, iar incidenţa infecţiei este invers proporţională cu vârsta gestaţională şi greutatea la naştere (BW) $(4,5)$.

La nivel mondial, Organizaţia Mondială a Sănătăţii (OMS) estimează că decesele neonatale reprezintă $44 \%$ dintre decesele globale, iar dintre acestea $26 \%$ sunt cauzate de infecţii $(6,7)$.

Dobândirea infecţiei poate avea loc în orice moment: ante, peri şi postnatal. Infecţiile postnatale pot fi transmise prin contact direct cu personalul spitalului, mamele, membrii familiei, lapte matern sau diverse suprafeţe contaminate (8).

Un alt aspect foarte important în evoluţia infecţiilor la nou-născuţi îl reprezintă sepsisul. Sepsisul neonatal este o cauză importantă a morbidităţii şi mortalităţii la nivel mondial. În 2015, infecţia a reprezentat $15 \%$ dintre cele 2,7 milioane de decese neonatale la nivel global. Se estimează că 150.000 de bebeluşi mor din cauza sepsisului în prima zi după naştere şi 300.000 până la sfầrşitul primei săptămâni (9). La nivel global, dintre cele 3.000.000 de cazuri anuale de sepsis neonatal (2.202/1.000.000 de naşteri vii), India are cea mai mare incidenţă de sepsis clinic (17.000/1.000.000 naşteri vii) (10).

La începutul anilor 1950, în America, Virginia Apgar a dezvoltat scorul APGAR, folosit până în prezent pentru a evalua sănătatea nou-născutului. Cei 5 parametri pe baza cărora se apreciază indicele APGAR sunt: respiraţia, frecvenţa cardiacă, reactivitatea la stimuli, tonusul muscular, aspectul tegumentelor - parametri care vor fi notaţi fiecare cu puncte de la 0 la 2 , astfel încât scorul poate fi cuprins între 0 şi 10 (11).

\section{SCOP}

Scopul studiului a fost identificarea unor factori predictivi ai infecţiilor neonatale cu debut precoce.

\section{MATERIAL ŞI METODE}

Am realizat un studiu prospectiv în cadrul Clinicii de Neonatologie din cadrul Spitalului Clinic Județean din Târgu Mureş, România, în perioada ianuarie 2017 - martie 2019, care a inclus 120 de nou-născuţi. Consimţământul informat din partea părinţilor sau a tutorilor legal a fost obţinul pentru fiecare pacient în parte.

Variabilele studiate au fost scorul APGAR la $1 \mathrm{mi}-$ nut şi 5 minute, tipul naşterii, greutatea la naştere şi la externare, diagnosticele la internare, hemoleucograma, antibioterapia, numărul de zile de spitalizare şi evoluţia pacientului. Datele au fost extrase din fişele pacienţilor.

Statistica analitică a fost realizată folosind soft-ul SPSS v17.0, iar pentru statistica descriptivă au fost folosite softurile GraphPad Prism 8 şi XLSTAT-Lite 2015 pentru Windows 10 Pro. Pentru eliminarea valorilor aberante, a fost utilizat testul Grubbs. Pentru identificarea distribuţiei gaussiene a datelor, a fost utilizat testul Kolmogorov-Smirnov; pentru datele parametrice a fost aplicat testul Pearson, respectiv testul Spearman pentru datele nonparametrice. Rezultatele au fost considerate semnificativ statistice pentru valori ale lui $p$ mai mici de 0,05 .

Studiul s-a desfăşurat conform principiilor Declaraţiei de la Helsinki şi a fost aprobat de Comisia de Etică a Universităţii de Medicină, Farmacie, Ştiinţe şi Tehnologie „George Emil Palade“ din Tg. Mureş nr. 71/27.04.2018.

\section{REZULTATE}

În cadrul studiului au fost incluşi 120 de nou-născuţi, 52 (43,3\%) de sex feminin şi 68 (56.7\%) de sex masculin, dintre care 8 au fost încadraţi în categoria cazurilor sociale. $15(12,5 \%)$ dintre cei 120 de pacienţi incluşi în studiu au avut nota 10 la scorul APGAR la 1 minut. La 5 minute, 57 pacienţi $(47,5 \%)$ au avut nota 10. În ceea ce priveşte tipul naşterii şi vârsta gestaţională, 59 (49,2\%) de pacienţi au fost născuţi pe cale vaginală şi $61(50,8 \%)$ prin cezariană; vârsta gestaţională medie fiind de 39,04 săptămâni. Greutatea medie la naştere a fost $3.197,33 \mathrm{~g}$, iar la externare a fost de 3.126,12 g. Media lungimii fătului a fost 51,62 $\mathrm{cm}$, iar media perimetrului cranian a fost $33,48 \mathrm{~cm}$.

Cel mai frecvent, pacienţii au prezentat patologie infecţioasă $(n=40)$, frecvent asociată cu afectarea sistemului pulmonar. Incidenţa la naştere a afecţiunilor pe sisteme de organe este prezentată în Figura 1. 


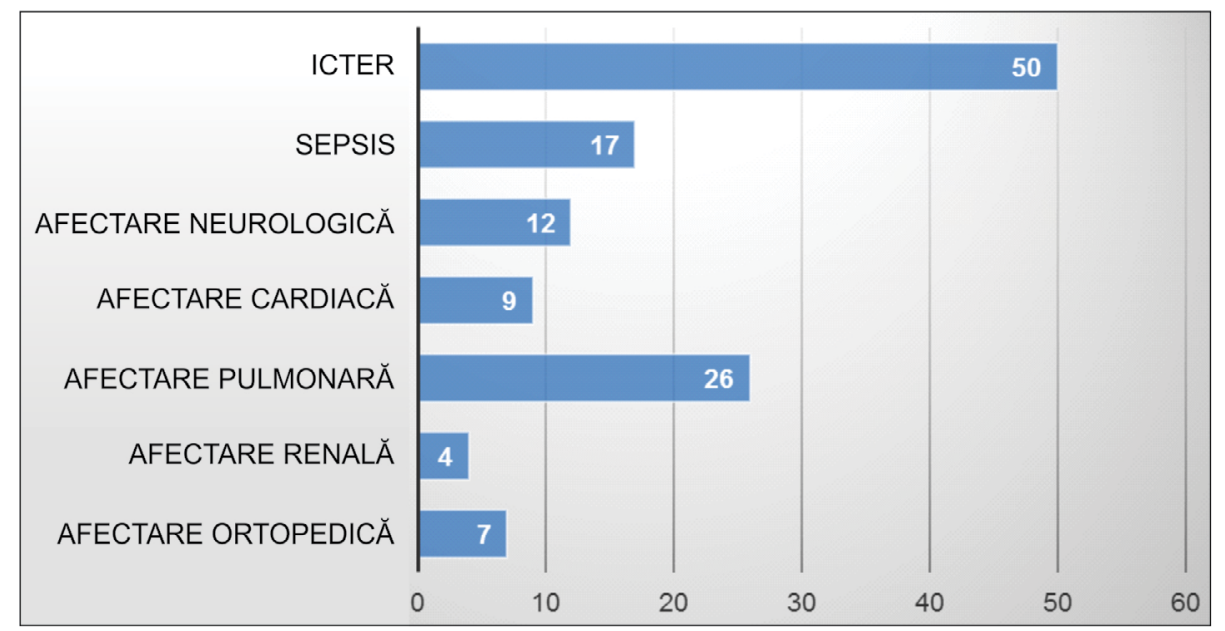

FIGURA 1. Incidența afecțiunilor pe sisteme de organe

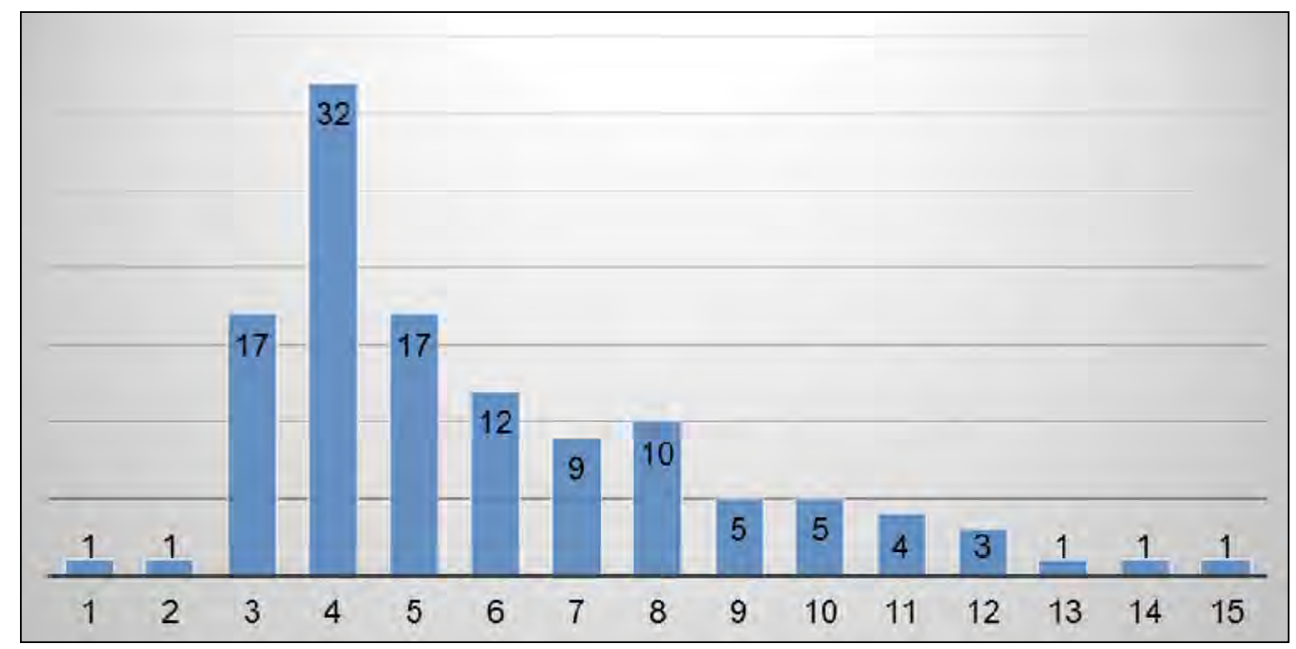

FIGURA 2. Repartizarea cazurilor pe număr de zile de internare

La cei 40 de nou-născuţi cu patologie infecţioasă a fost prezentă infecţia neonatală precoce.

Cei mai mulţi au fost internaţi timp de 4 zile, cu o medie de spitalizare de 6,15 zile. Distribuţia pacienţiilor pe zile de internare este prezentată în Figura 2.

În cadrul studiului, au fost analizate corelaţiile dintre valorile parametrilor obţinuţi din hemoleucogramă (hemoglobină, hematocrit, leucocite, limfocite, neutrofile, monocite şi trombocite) şi numărul de zile de internare, scorul APGAR la 1 minut şi 5 minute şi valorile proteinei $\mathrm{C}$ reactive.

În studiul nostru, am obţinut o medie a valorilor proteinei $\mathrm{C}$ reactive recoltate în primele 24 de ore de la internare în rândul nou-născuţilor cu infecţii de $8,87 \mathrm{mg} / \mathrm{dl}$. Am considerat această valoare ca un factor predictiv în ceea ce priveşte statusul infecţios al nou-născuţilor.

Dintre parametrii analizaţi, am obţinut o corelaţie negativă semnificativ statistică între nivelul scorului
APGAR la 1 minut ( $p=0,0054, \mathrm{r}=-0,2558)$ şi la 5 minute $(p=0,0003, \mathrm{r}=-0,3276)$, în raport cu zilele de internare. De asemenea, pentru paritate, în raport cu zielele de internare, am obţinut o corelaţie negativă semnificativ statistică $(p=0,0426, \mathrm{r}=-0,1894)$.

În urma aplicării testului $\mathrm{Chi}^{2}$ a fost identificată o relaţie de dependenţă semnificat statistică $(p=0.0264)$ între scorul APGAR la 1 minut şi statusul infecţios al pacienţilor.

Dintre cei 120 de pacienţi incluşi în studiu, 50 $(41,66 \%)$ au primit tratament antibiotic, dintre care 10 pacienţi $(12 \%)$ au primit tratament profilactic. 33 (27,5\%) dintre pacienţi au primit Ampiplus împreună cu Amikacin sau Gentamicină; 15 (12,5\%) au primit Ampicilină împreună cu Gentamicină. Dintre aceştia, 19 pacienţi (38\%) s-au vindecat şi 25 (50\%) au avut o stare ameliorată.

La externare, $60(50 \%)$ de pacienţi au fost vindecaţi, $51(42,5 \%)$ au prezentat o stare ameliorată, 5 
TABELUL 1. Corelații statistice pentru scorul APGAR

(la 1' şi la 5')

\begin{tabular}{|c|c|c|c|c|c|c|c|c|}
\hline \multirow{2}{*}{$\begin{array}{l}\text { Variabile } \\
\text { analizate }\end{array}$} & \multicolumn{2}{|c|}{ APGAR $1^{\prime}$} & \multicolumn{2}{|c|}{ APGAR $5^{\circ}$} & \multicolumn{2}{|c|}{ Gestaţie } & \multicolumn{2}{|c|}{ Paritate } \\
\hline & $n$ & $p$ & $n$ & $p$ & $n$ & $p$ & $n$ & $p$ \\
\hline \multirow{2}{*}{$\begin{array}{l}\text { Zilele de } \\
\text { internare }\end{array}$} & \multirow{2}{*}{119} & 0,0054 & \multirow{2}{*}{119} & 0,0003 & \multirow{2}{*}{118} & \multirow{2}{*}{0,3652} & \multirow{2}{*}{119} & 0,0426 \\
\hline & & $r=-0,2558$ & & $r=-0,3276$ & & & & $r=-0,1894$ \\
\hline $\begin{array}{c}\text { Greutatea la } \\
\text { naștere }\end{array}$ & 120 & 0,4382 & 120 & 0,2246 & 118 & 0,5012 & 116 & 0,79603 \\
\hline
\end{tabular}

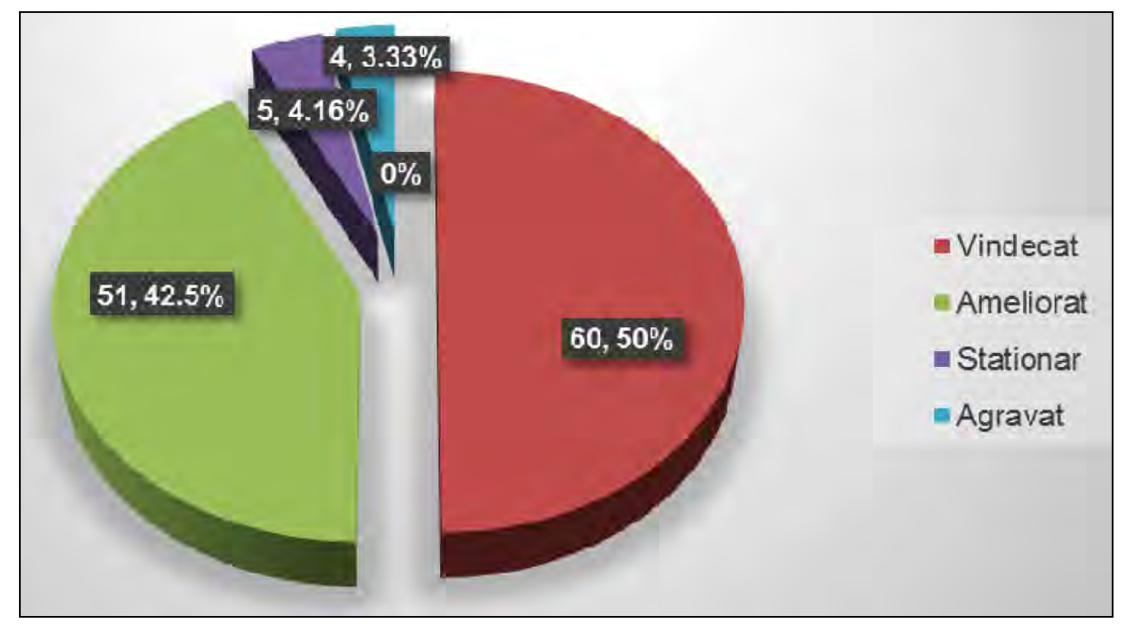

FIGURA 3. Starea la externare a pacienților

$(4,16 \%)$ au avut o evoluţie staţionară, iar $4(3,33 \%)$ au avut un status agravat (Figura 3).

\section{DISCUȚII}

Infecţia neonatală reprezintă una dintre cele mai importante cauze care influențează rata mortalităţii şi morbidităţii la nou-născuţi. Greutatea scăzută la naştere, anemia şi vârstă mică a mamei sunt considerate a fi factori de risc importanţi în ceea ce priveşte statusul infecţios al nou-născutului. Gravitatea infecţiei la nou-născuţi este dată de faptul că aceasta poate evolua cu uşurinţă spre sepsis, ceea ce reprezintă $10 \%$ dintre cauzele mortalităţii la nou-născuţi, la ora actuală fiind una dintre cele mai mari provocări din domeniul neonatologiei $(12,13)$.

În literatura de specialitate, infecţia neonatală se subclasifică în infecţie cu debut precoce, care apare în mai puţin de 72 de ore de la naştere, şi infecţie cu debut tardiv, la mai mult de 72 de ore de la naştere (14). Deşi infecţia neonatală cu debut tardiv este mult mai frecventă decât cea cu debut precoce, aceasta din urmă are o evoluţie mai agresivă, cu un prognostic mai rezervat. Incidenţa mondială a apariţiei infecţiei neonatale cu debut tardiv este de 61 la 1.000 de nounăscuţi, respectiv a infecţiei neonatale cu debut preco- ce este de 9 la 1.000 de nou-născuţi. Majoritatea cazurilor de infecţii cu debut precoce $(80-90 \%)$ se manifestă în primele 48 de ore de viaţă (15). În studiul nostru, am urmărit evoluţia a 40 de nou-născuţi din lotul studiat $(n=120)$, care au dezvoltat infecţii în primele 72 de ore de la naştere. $\mathrm{O}$ altă diferenţă din punctul de vedere al organismelor patogene identificate în fiecare tip de infecţie neonatală este reprezentată de faptul că la infecţie neonatală cu debut tardiv sunt întâlniţi Streptococcus tip B (în 54\% dintre cazuri), Enterobacteriaceae (21\%) şi Staphylococcus aureus (18\%), iar în cazul infecţiilor cu debut precoce sunt întâlniţi Streptococus agalactiaei aparţinând grupului B, reprezentând 58\%, şi Escherichia coli, cu $18 \%$ dintre infecţii. Agenţii care provoacă infecţii congenitale sau perinatale pot duce la pierderea permanentă a auzului, pierderea vederii, tulburări cognitive, paralizie cerebrală, întârziere în dezvoltare, tulburări de comportament sau epilepsie. Efectuarea hemoculturii şi identificarea factorului patogen sunt esenţiale în instituirea tratamentului corespunzător şi eficient.

De asemenea, cunoaşterea simptomelor şi antecedentelor materne, precum şi a rezultatelor de screening al infecţiilor materne în ultimul trimestru de sarcină trebuie luate în considerare. De regulă, în 
tratamentul acestor infecţii se administrează Ampicilină şi un aminoglicozid, acestea fiind considerate antibiotice $\mathrm{cu}$,spectru larg“, acoperind infecţiile cu streptococi, E. coli sau majoritatea altor agenţi patogeni frecvent întâlniţi (16-18). Acest fapt se corelează cu datele care reies din studiul nostru, unde în majoritatea cazurilor s-a administrat Ampiplus cu Amikacin sau Gentamicina, ultimele două aparţinând clasei aminoglicozidelor.

Recomandările internaţionale indică 7-10 zile de tratament în prezenţa infecţiilor bacteriene confirmate microbiologic sau în cazul celor neconfirmate, însă cu o prezentare clinică puternică. În prezenţa unui test negativ de hemocultură după 36-48 de ore şi în absenţa unei suspiciuni clinice puternice de infecţie neonatală, trebuie luată în considerare întreruperea terapiei antibacteriene. Literatura ştiinţifică nu recomadă nicio altă durată a tratamentului şi, prin urmare, o durată de antibioterapie de 5 sau 6 zile ridică îndoieli cu privire la eficacitatea antibioterapiei în astfel de circumstanţe.

Media zilelor de internare din studiul nostru la pacienţii cu infecţie este de 8,4 zile, aceasta coincide în majoritatea cazurilor cu numărul de zile de administrare a antibioterapiei. Respectarea conduitei medicale se observă şi în faptul că doar 4 dintre cei 50 de nou-născuţi ce au urmat antibioterapia au avut evoluţie nefavorabilă $(19,20)$. Detresa respiratorie reprezintă acumularea de fluid la nivel pulmonar care determină o respiraţie îngreunată. Aceasta este frecvent întâlnită în prima fază la nou-născuţi, în special la cei născuţi în urma operaţiilor cezariene, şi se remediază adesea în doar câteva ore. Nou-născuţii consideraţi a fi stabili şi care nu prezintă factori de risc perinatal pentru a dezvolta sepsis pot fi ţinuţi sub observaţie până la 6 ore pentru a determina dacă sindromul funcţional respirator se rezolvă înainte de a continua investigaţiile pentru sepsis şi de a începe antibioterapia (21). În studiul nostru, acesta a fost prezent la 10 nounăscuţi, iar 6 dintre ei au avut o evoluţie gravă înspre pneumonie de aspiraţie, respectiv sepsis. Toţi au urmat tratament cu antibiotic.

În unele publicaţii, a fost raportată asocierea dintre nivelurile normale ale proteinei $\mathrm{C}$ reactive (PCR) din testele serologice cu o probabilitate de infecţie semnificativ scăzută, cu raporturi de probabilitate cuprinse între 0,03 şi 0,16 . Nivelurile maxime ale PCR mai mari de $3 \mathrm{mg} / \mathrm{dl}$ au valori predictive pozitive mai mari de $20 \%$ pentru infecţiile cu debut precoce, respectiv tardive, însă doar cele cu valori de peste $6 \mathrm{mg} / \mathrm{dl}$ au o valoare predictivă pozitivă foarte crescută pentru infecţiile neonatale, respectiv sepsis cu debut precoce (6). Nivelurile din sânge ale proteinei $\mathrm{C}$ reactive sunt utile în evaluarea diagnostică a nou-născuţilor care prezintă suspiciune de sindrom infecţios. S-a demonstrat în studii anterioare că două niveluri ale proteinei $\mathrm{C}$ reactive mai mici de $1 \mathrm{mg} / \mathrm{dl}$ obţinute la 24 de ore distanţă una de cealaltă, la 8 până la 48 de ore de la prezentare, indică faptul că infecţia bacteriană este puţin probabilă. Sensibilitatea unei valori ale proteinei $\mathrm{C}$ reactive normale la evaluarea iniţială nu este suficientă pentru a justifica lipsa administrării antibioterapiei $(22,23)$.

În studiul nostru, am obţinut o relaţie semnificativ statistică între scorul APGAR (la 1 minut și la 5 minute) şi statusul infecţios al nou-născuţilor. Relaţia dintre scorul APGAR mai mic de 7 la naştere şi mortalitatea infantilă este atribuită în principal anoxiei sau infecţiilor, însă şi un scor APGAR relativ normal, cuprins între 7 şi 9, poate fi urmat de prezenţa unei infecţii neonatale şi, de asemenea, poate fi asociat cu riscuri mari de mortalitate şi morbiditate neonatală. $\mathrm{Cu}$ cât scorul APGAR se menţine la o valoare mai mică la 5 minute, cu atât acest risc creşte. Relaţiile puternice între scorurile APGAR de 7, 8 şi 9 şi morbiditatea neonatală observate în studiul nostru oferă o perspectivă asupra riscurilor crescute de apariţie a infecţiilor la aceste valori faţă de un scor 10 la 1 minut, respectiv 5 minute.

De aceea, din ce în ce mai multe studii se axează pe profilaxia necesară unui scor APGAR de 10 (24). Similar datelor din literatură, am obţinut în studiul nostru faptul că dintre cei 15 (18\%) nou-născuţi incluşi în studiu ce au obţinut scorul APGAR 10 la 1 minut, niciunul nu a suferit de patologii infecţioase şi aceştia au necesitat cele mai puţine zile de spitalizare. 10 pacienţi $(21,2 \%)$ dintre cei 47 de nou-născuţi ce au fost iniţial evaluaţi cu un scor APGAR mai mic de 10, cuprins în 7 şi 9 la 1 minut şi care ulterior la 5 minute au obţinut un scor APGAR de 10, au suferit de patologii infecţioase.

Cea mai importantă limitare a studiului a fost numărul relativ mic de pacienţi $(n=120)$. Alte limitări: am analizat datele dintr-o singură clinică de neonatologie şi nu am inclus în studiu şi nou-născuţii prematuri, care au fost trataţi în alt centru. 


\section{CONCLUZII}

Patologia cel mai frecventă întâlnită în rândul nounăscuţilor a fost de natură infecţioasă. Scorul APGAR la 1 minut şi la 5 minute a reprezentat în studiul nostru cel mai fidel indicator pentru riscul de infecţie neona-

\section{BIBLIOGRAFIE}

1. Borghesi A, Stronati M, Castagnoli R et al. Novel Approaches to the Study of Neonatal Infections. Am J Perinatol. 2018;35(6):570-574.

2. Levy O. Innate immunity of the newborn: Basic mechanisms and clinical correlates. Nat Rev Immunol. 2007;7(05):379-390.

3. Perez GF, Pancham K, Huseni S, Jain A, Rodriguez-Martinez CE, Preciado $D$ et al. Rhinovirus-induced airway cytokines and respiratory morbidity in severely premature children. Pediatr Allergy Immunol. 2015;26:145-52.

4. Darlow BA, Voss L, Lennon DR et al. Early-onset neonatal group B streptococcus sepsis following national risk-based prevention guidelines. Aust N Z J Obstet Gynaecol. 2016;56:69-74.

5. Singh T, Barnes EH, Isaacs D; Australian Study Group for Neonatal Infections. Early-onset neonatal infections in Australia and New Zealand, 2002-2012. Arch Dis Child Fetal Neonatal Ed. 2019; 104(3):F248-F252.

6. Darmstadt GL, Marchant T, Claeson M et al. A strategy for reducing maternal and newborn deaths by 2015 and beyond. BMC Pregnancy Childbirth. 2013;13:216.

7. World Health Organization. World Health Report 2005: Make Every Mother and Child Count. Geneva: World Health Organization; 2005.

8. Yoon HS, Shin YJ, Ki M. Risk factors for neonatal infections in full-term babies in South Korea. Yonsei Med J. 2008;49(4):530-536.

9. UNICEF. The neonatal period is the most vulnerable time for a child UNICEF, Neonatal Mortality, 2016. https:// data. unicef. org/ topic/ child- survival/ neonatal- mortality/ (accessed 21 Aug 2017).

10. Fleischmann-Struzek C, Goldfarb DM, Schlattmann P, Schlapbach LJ, Reinhart K, Kissoon N. The global burden of paediatric and neonatal sepsis: A systematic review. Lancet Respir Med. 2018; 6(3):223-230.

11. Cnattingius S, Norman M, Granath F, Petersson G, Stephansson O, Frisell T. Apgar Score Components at 5 Minutes: Risks and Prediction of Neonatal Mortality. Paediatr Perinat Epidemiol. 2017; 31(4):328-337.

12. Simonsen KA, Anderson-Berry AL, Delair SF, Davies HD. Early-onset neonatal sepsis. Clin Microbiol Rev. 2014;27(1):21-47.

13. Lim JW, Chung SH, Kang DR, Kim CR. Risk Factors for Cause-specific Mortality of Very-Low-Birth-Weight Infants in the Korean Neonatal Network. J Korean Med Sci. 2015. tală. Valorile sale s-au corelat şi cu numărul de zile de internare. De asemenea, numărul de zile de internare s-a corelat cu paritatea. Tratamentul urmat de majoritatea pacienţilor a fost asocierea dintre o betalactamină şi un antibiotic din clasa aminoglicozidelor.

14. Haque K. Definitions of bloodstream infection in the newborn. Pediatr Crit Care Med. 2005;6(3 Suppl):S45-9.

15. National Institute for Health and Care Excellence (NICE). Antibiotics for neonatal infection. NICE quality standard 75. 2014; guidance. nice.org.uk/qs75, p.5.

16. National Collaborating Centre for Women's and Children's Health. Antibiotics for early-onset neonatal infection: antibiotics for the prevention and treatment of early-onset neonatal infection. Royal College of Obstetricians and Gynaecologists. 2012.

17. Maródi L. Neonatal innate immunity to infectious agents. Infect Immun. 2006 Apr;74(4):1999-2006.

18. Velaphi S, Siegel JD, Wendel GD Jr, Cushion N, Eid WM, Sanchez PJ. Early-onset group B streptococcal infection after a combined maternal and neonatal group B streptococcal chemoprophylaxis strategy. Pediatrics. 2003;111(3):541-7.

19. NICE clinical guideline. Antibiotics for early-onset neonatal infection: Antibiotics for the prevention and treatment of earlyonset neonatal infection. Available from: http://www.nice.org.uk/ guidance/CG149, date of publication: August 2012.

20. Escobar GJ, Puopolo KM, Wi S et al. Stratification of risk of early-onset sepsis in newborns $\geq 34$ weeks' gestation. Pediatrics. 2014;133(1):30-36.

21. Brown JVE, Meader N, Wright K, Cleminson J, McGuire W. Assessment of C-Reactive Protein Diagnostic Test Accuracy for Late-Onset Infection in Newborn Infants: A Systematic Review and Meta-analysis [published online ahead of print, 2020 Feb 3]. JAMA Pediatr. 2020;174(3):260-268.

22. Ahmed E, Rehman A, Ali MA. Validation of serum C-reactive protein for the diagnosis and monitoring of antibiotic therapy in neonatal sepsis. Pak J Med Sci. 2017;33(6):1434-1437.

23. Gutbir $Y$, Wainstock $T$, Sheiner $E$ et al. Low Apgar score in term newborns and long-term infectious morbidity: A population-based cohort study with up to 18 years of follow-up. Eur J Pediatr. 2020; 179(6):959-971.

24. Razaz N, Cnattingius S, Joseph KS. Association between Apgar scores of 7 to 9 and neonatal mortality and morbidity: Population based cohort study of term infants in Sweden. BMJ 2019;365:11656.

Conflict of interest: none declared Financial support: none declared 